\title{
ПСИХОЛОГІЧНИЙ СУПРОВІД СУЧАСНОГО ВИХОВНОГО ПРОЦЕСУ
}

\author{
Наукова доповід ь на загальних зборах НАПН України 17 грудня 2019 р. \\ https://doi.org/10.37472/2707-305X-2019-1-1-1-3
}

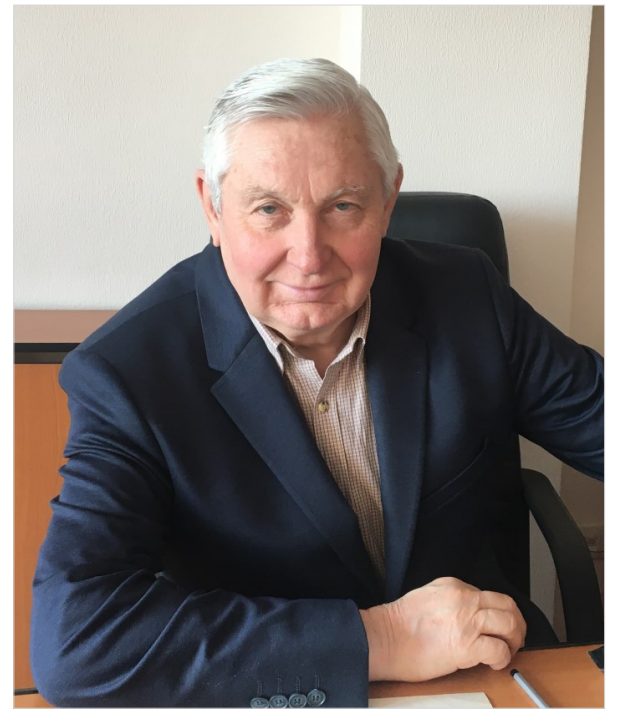

\section{БЕХ Іван Дмитрович}

доктор психологічних наук, професор, дійсний член (академік) НАПН України, директор Інституту проблем виховання Національної академії педагогічних наук України, м. Київ, Україна

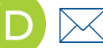

Анотація. Констатується ситуація, яка за пріоритет покладає рачіоналізм як жорстко нормовану стратегію в освітньому процесі. У цих умовах зростаюча особистість формується лише частково, оскільки нейтралізуються фрактори повноцінного інтелектуального розвитку та духовності у їх цілісності.

Згадана ситуація може бути трансформована за умови утвердження цінності як одиниці різнобічного розвитку особистості. З огляду на це провідним механізмом ціннісного осягнення світу зростаючою особистістю виступає психологічний супровід освіти, зокрема виховного процесу. Пропонується наступна дефініція. Сутністю психологічного супроводу доцільно вважати освітню дію (рівною мірою і навчальну, і виховну), індикатором якої виступає глибока наукомісткість, що складається з ряду наукових закономірностей педагогічної психології, психології спілкування, психології мотивації, психолінгвістики. Означені дисципліни роблять освітню дію більш ефективною у пізнавальному і розвивальному плані, а традиційний освітній метод, збагачений психологічним супроводом, підноситься до рівня технології у вузькому розумінні цього терміну.

Під духовно-моральним розвитком пропонується розуміти набуття вихованцем нових за природою, тобто вищих переживань справедливості, честі, вірності, любові, альтруїму тощо. Означена розвивальна ідея, яка грунтується на психологічному супроводі, кваліфікується як інноваційна парадигма. ї̈ конструктивна побудова має здійснюватися на основі діалектичного дискурсу як несуперечливому сходженні від фрілософрького бачення до конкретних виховних методик. Відповідно психологічний супровід організовувався на чотирьох рівнях: фрілософському, методологічному, теоретичному та методичному. Принципові положення філософрськометодологічного й теоретичного рівнів об'єктивуються у певних розвивальних методах.

Ключові слова: виховний процес; духовна цінність; інноваційна парадигма; методологічне підгрунтя; психологічний супровід; раціоналізм; розвивальні методи.

Турбота про духовно розвинену особистість нині - не просто громадянське гасло, яке прийшло на зміну іншим пріоритетам. Це справжній біль суспільства. Адже деіндивідуалізація і дегуманізація особистості дійшли до крайньої межі. Непомірно культивується раціоналізм мислення, коли людина діє лише жорстко нормативно. Відтак, зникає чуттєве осягнення світу в цілому й усіх його складових. Романтика життя стає чужою сучасній людині.

У цьому зв'язку слід зазначити, що традиційні теорія і методика виховання з їх принципами і засобами не відповідають нинішнім виховним цілям. Усі ці особистісно перетворювальні інструменти переглядаються, натомість широко апробуються 
інноваційні. Це факт новітньої парадигми, зокрема, на даний час уводяться нові наукові категорії: життя як вчинок, вищі смисли, смислоціннісна сфера, духовність як вираз духу, суб'єкт життя в духовності, Я-духовне, духовна рефлексія. Усі вони, залежно від конкретної виховної мети, селективно використовуються як для розроблення дослідницьких проектів, так і для побудови на основі їх результатів практико-перетворювальних проектів, де духовна зрілість вихованця стає мірою продуктивності зазначених засобів. Це стало можливим у кінцевому підсумку завдяки глибинному психологічному супроводу.

Сутністю психологічного супроводу доцільно вважати освітню дію (рівною мірою і навчальну, і виховну), індикатором якої виступає глибока наукомісткість, що складається з ряду наукових закономірностей педагогічної психології, психології спілкування, психології мотивації, психолінгвістики. Означені дисципліни роблять освітню дію більш ефективною у пізнавальному і розвивальному плані, а традиційний освітній метод, збагачений психологічним супроводом підноситься до рівня технології у вузькому розумінні цього терміну.

Психологічний супровід сучасного виховного процесу має забезпечити саме повноцінний духовно-моральний розвиток зростаючої особистості. Якраз розвиток, під яким розумітимемо набуття вихованцем нових за природою, а це означає культуроспричинених почуттів, тобто вищих переживань справедливості, честі, вірності, альтруїзму, любові тощо. Такі почуття не можуть виникнути на основі стимул-реактивної схеми як виховання, що ґрунтується на методах зовнішнього підкріплення. Тож потрібна нова інноваційна парадигма. Ії̈ побудова здійснювалась нами на основі діалектичного дискурсу як несуперечливе сходження від відповідного філософського бачення до конкретних виховних методик. Таким чином, психологічний супровід здійснювався на чотирьох рівнях: філософському, методологічному, теоретичному і методичному. Філософія екзистенціоналізму слугувала нам проголошенням цінностей як смислових орієнтацій життя людини. Тому духовна цінність покладалася нами як вихідна клітинка організації виховного процесу.

Методологічним підґрунтям психологічного супроводу інноваційного виховного процесу виступають:

1. Положення Л.С. Виготського, згідно з яким динамічною одиницею свідомості особистості $€$ не процес розуміння, а переживання. Якраз у переживанні наявний, з одного боку, компонент пізнання, а з іншого - ставлення до пізнаного. Це $\epsilon$ когнітивно-емоційна цілісність як репрезентант свідомості. «Переживання має біосоціальне орієнтування, воно є тим, що знаходиться між особистістю і середовищем, означає відношення особистості до середовища, свідчить, чим даний момент середовища виступає для особистості».

2. Положення Ф. Лерша про діалогічну природу людини. Згідно з ним людина є тим, чим вона $€$, завдяки способу, яким відображає враження від навколишнього світу, і як поводить себе в ньому. Поведінка здійснюється завжди у постійному круговому процесі комунікації індивіда зі світом; вони становлять, власне кажучи, діалог між людиною і світом. Відтак душа і світ утворюють полярно-співіснуючу єдність.

3. Положення Д. Міллера, Ю.Галантера, К. Прибрама про особливості планів і структури людської поведінки. Надзвичайно важливою у цьому плані $є$ думка про «План» як послідовність дій, що утверджують ієрархічну систему поведінки. Знання повинні бути включеними в План, оскільки в іншому випадку План не може служити основою для керівництва поведінкою, а згадана система, на думку вчених, єєдино правильною.

Наступний теоретичний крок: вичленення необхідних і достатніх методологічних підходів як стратегічних інваріантів організації гуманістично розвивального виховного процесу. У подібній функції дієвими виступили: особистісноорієнтований, дитино-центрований, аксіологічний і акмеологічний підходи. Це ті рамкові межі, які мають структурувати реально діючий процес виховання. Наше авторське бачення особистісноорієнтованого підходу узгоджує його у якості доповнюваності стосовно перелічених вище підходів. Тож основними постулатами особистісноорієнтованого підходу виявились: глибоке розуміння вихованця, прийняття вихованця, його безумовне визнання та утвердження взаємин справедливості.

Вимогам методологічного підходу відповідають принципи як зовнішні способи організації процесу виховання. До них ми віднесли принцип культуровідповідності, гармонізації та індивідуації як набуття самості (Я-духовного).

За методологічним правилом сходження вичленені принципи об'єктивуються у певні розвивальні методи. 
На даний час широко використовуються як у дослідницьких, так і практичних цілях методи:

- переконання;

- інтимно-особистісного діалогу;

- поетапного сходження до цінностей;

- генезо-моделювальний;

- рефлексивно-експліцитний.

В основу кожного з цих методів покладається духовна цінність, яка має бути керовано (в першому наближенні) вихована у того чи іншого вихованця.

Тож духовну цінність ми розглядаємо як таку, що інтегрується в структуру Я-духовного особистості. Подібна інтеграція збільшує соціальний ареал ії практичної самореалізації у поведінці, діяльності, спілкуванні особистості. Константою духовної цінності особистості є її налаштованість поводитись подібним чином у різних (але не в будь-яких) ситуаціях. Тож доцільно констатувати два аспекти стабільності поведінки особистості стабільність у часі і стабільність відносно різних ситуацій.

На відміну від цінності як емпірично рівневої закономірності і як описової одиниці ми утверджуємо теоретично-пояснювальну цінність як закономірність, тобто як когнітивно-емоційну єдність, що розвивається у своїй досконалості.
Наша теорія виховання - це теорія цінностей як пояснювальних закономірностей, і в цьому ї̈ відмінність від аналогічних емпіричних побудов. По-іншому, ми створюємо психопедагогічну теорію виховання або духовно-моральну теорію.

На вищевикладених ідеях психологічного супроводу в Інституті проблем виховання НАПН України вперше 3 усіх наукових установ та прийнятих пізніше державних документів було презентовано Програму національнопатріотичного виховання дітей та учнівської молоді. Протягом 2014-2019 рр. в Інституті проведено ряд фундаментальних і прикладних досліджень з питань формування моральної самосвідомості та національно-культурної ідентичності особистості, військово-патріотичного виховання старшокласників та формування готовності до захисту Вітчизни. Ми проводимо навчальні семінари-тренінги «3 Україною в серці», «Окрилені Україною» 3 питань формування національнокультурної ідентичності для освітян, молодіжних працівників, дитячого активу, дитячих громадських організацій.

I, насамкінець, наша різнобічна у цьому плані експериментальна робота втілилась, зокрема, у створену «Програму сходження зростаючої особистості до духовних цінностей», схвалену МОН України, і яка широко використовується у різних регіонах нашої країни.

\section{PSYCHOLOGICAL SUPPORT OF THE MODERN EDUCATIONAL PROCESS Scientific report at the General Meeting of the National Academy of Educational Sciences of Ukraine, December 17, 2019}

Ivan Bekh

DSc in Psychology, Professor, Full Member (Academician) of NAES of Ukraine, Director, Institute of Problems on Education of the National Academy of Educational Sciences of Ukraine, Kyiv, Ukraine

Abstract. The report deals with the situation that prioritizes rationalism as a rigidly normalized strategy in the educational process. In these circumstances, the growing personality is formed only partially, since the factors of complete intellectual development and spirituality in their integrity are neutralized.

This situation can be transformed, provided a value as a unit of personal development. The psychological mechanism of education, in particular, the educational process is the leading mechanism of value understanding of the growing personality. The following definition is proposed: the essence of psychological support is an educational action (both teaching and learning), the indicator of which is deep knowledge-intensive consisting of a number of scientific laws of pedagogical psychology, psychology of communication, psychology of motivation, psycholinguistics. These disciplines make educational action more effective in cognitive and developmental terms, as well as the traditional educational method enriched with psychological support rises to the level of technology in the narrow sense of this concept.

Spiritual and moral development is considered as the acquisition by the student new, higher level experience of justice, honor, faithfulness, love, altruism, etc. This developmental idea, which is based on psychological support, is qualified as an innovative paradigm. Its constructive meaning should be carried out on the basis of dialectical discourse as a consistent ascent from philosophical vision to specific educational methods. Accordingly, psychological support was organized at four levels: philosophical, methodological, theoretical and methodical. The key principles of philosophical, methodological and theoretical levels are objectified in certain developmental methods.

Keywords: educational process; spiritual value; innovative paradigm; methodological basis; psychological support; rationalism; developmental methods. 